\title{
A hagyományos és tudományos agroökológiai ismeretek ötvözésének szükségszerüsége a felsőoktatási képzésekben
}

\author{
Ujj Apolka ${ }^{1}$ és Fehér István ${ }^{2}$ \\ ${ }^{1}$ Szent István Egyetem, Mezögazdaság- és Környezettudományi Kar, Természetvédelmi és \\ Tájgazdálkodási Intézet, Ökológiai gazdálkodási és Agrár-környezettervezési Tanszék, \\ Gödöllö 2100, Páter K. u.1. \\ ${ }^{2}$ Szent István Egyetem, Gazdaság- és Társadalomtudományi Kar, Üzleti Tudományok \\ Intézete, Gödöllö 2100, Páter K. u.1. \\ e-mail:ujj.apolka@mkk.szie.hu
}

Összefoglaló: Az agroökológia oktatása - holisztikus szemléletmódjából adódóan - jelentős kihívás elé állítja a felsőoktatásban dolgozó oktatókat is. A SAGITER nevü nemzetközi projekt munkatársai azt a célt tüzték ki maguk elé, hogy a hagyományos, sok esetben csak tapasztalaton alapuló, tudományosan nem megalapozott, un. informális ökológiai tudást ötvözik a kutatáson alapuló, formális tudományos ismeretekkel. Magyarországon a leghatékonyabb tudásátadás módszertan kiválasztásához mindenképpen szükséges a meglévő ismeretek feltérképezése. Ebből a célból BSc, BA és MSc hallgatók között írásos felmérést végeztünk az agroökológiai rendszerek témakörében, az ökológiai gazdálkodásra fektetve a hangsúlyt. Az eredmények tükrében megállapítható, hogy szignifikáns eltérés figyelhető meg a hallgatók tudásszintje között, ami adódik alapképzésük jellegéből, képzés- és évfolyamszintjükből, valamint a válaszadók neme is befolyásoló tényezőt jelent. A hallgatók az ökológiai gazdálkodás környezetre gyakorolt hatását igen, de társadalmi és ökonómiai vetületét nem ismerik. Tudásszintjük legmeghatározóbb tényezője a korábban mezőgazdaságban szerzett tapasztalatuk, személyesen szerzett élményeik. A felmérés eredményei azt erősítik, hogy a felsőoktatásban is szükség van a gyakorlatiasabb képzés irányába történő elmozdulásra. Megoldásként kidolgoztunk egy olyan képzési palettát, amelyben a modulok a tapasztalt tudáshiányosságokat fedik le, különös tekintettel az agroökológia ökonómiai, társadalmi aspektusaira a környezetvédelem mellett.

Kulcsszavak: Agroökológia, ökológiai gazdálkodás, képzési program, egészség, gondosság, környezetvédelem, méltányosság, tudásátadás

\section{Bevezetés}

A nemzetközi szakirodalom éppúgy, mint számos hazai szerző, különféle megközelítésekben határozza meg és értelmezi a fenntarthatóság fogalmát. Az eltérő megfogalmazások közös nevezőjével azonban mindenki egyetért, miszerint a 
fenntarthatóság a „világ megóvásának egy olyan stratégiája, ami magában kell, hogy foglalja a természeti erőforrások olyan felhasználását, mely úgy képes kielégíteni a jelenlegi generáció igényeit, hogy azzal nem csökkeni az elkövetkezendő nemzedék esélyeit" (Douglass 1984, Harnos 1993, Glickman 1996, Ángyán \& Menyhért 1997, Ujj 2002). Ez a definíció magába foglalja azt is, hogy a mezőgazdasági termelés során ésszerủen kell gazdálkodni a természeti erőforrásokkal, mégpedig úgy, hogy közben közös nevezőre jusson a gazdaságossági fenntarthatóság a környezeti fenntarthatósággal, szem elött tartva a környezet minőségének megőrzését, és a társadalom korszerü és egészséges táplálkozással szemben támasztott egyre növekvő igényeit (Rovira 1995, Fehér 2009). Általánosságban megfogalmazható, hogy a természetes táj elsőszámú használója és egyben átalakítója maga a mezőgazdaság, amelyből az következik, hogy a természet védelmét ezért össze kell hangolni a mezögazdasági tevékenységgel. Ez fordítva is igaz, miszerint a mezőgazdasági tevékenység sikerességét, annak teljesítményét elsősorban az adott táj, a termőhely adottságai, a természeti erőforrások megléte, illetve azok állapota határozzák meg (OECD 2008, Günal et al. 2015). Ezek ismeretében megállapítható, hogy bár nem tünik bonyolultnak a fenntarthatóság alapcéljának teljesítése, mégsem könnyü megítélni azt, hogy mely termesztési rendszerek és módszerek felelnek ennek meg. A FAO (2003) mezőgazdasági rendszereit elemző kiadványában számos megközelítést (úgymint integrált növényvédelem, polikultúrára alapozott gazdálkodás, talajvédő gazdálkodás, ökológiai gazdálkodás, agroökológiai szemléletü gazdálkodás) értékel az alapján, hogy az hogyan ötvözi és használja fel a hagyományos tudást és bevált gyakorlatot a „modernkori” ismeretekkel és korszerü technológiával.

Az agroökológia - mint tudományág - a mezőgazdaság tanulmányozásához egy olyan ökológiai perspektívából közelít, amely a mezőgazdasági rendszernek, mint egésznek a stabilitásával és optimalizálásával foglalkozik. Az agroökológiai szemléletü gazdálkodás a hagyományos gazdálkodás jól bevált ismeretein alapszik, amely termelékenységi mutatóit tekintve esetlegesen elmaradhat a monokultúrára alapozott iparszerü mezőgazdálkodástól, azonban fenntarthatósága jóval perspektivikusabb, és egyben energiakímélőbb is (Altieri 1987). A hagyományos paraszti tudás ötvözése a korszerủ agroökológiai ismeretekkel, ezáltal egy valódi holisztikus megközelítés érvényesítése a gazdálkodás során azonban igazi kihívást jelent. Igazi kihívás nem csak a mezőgazdálkodás, de már a gyakorlatot megelőző oktatás és kutatás során is.

Ezek ismeretében a SAGITER nemzetközi projekt (Agroökológiai tudástranszfer, Egész életen át tartó tanulás program, Leonardo Da Vinci innováció alprogram) résztvevői azt a célt tüzték ki maguk elé, hogy a tudományos és a tapasztalati tudás (tudományosan nem feltétlenül megalapozott tudás) összekapcsolásával olyan 
innovatív megoldásokat dolgoznak ki az agroökológiai tudásátadás módszereire, amivel a fenntartható mezőgazdaság oktatása hosszú távon eredményes lehet. A SAGITER projekt számos megválaszolandó kérdést vet fel: El kell-e fogadnunk azt a széles körben elfogadott ,aszimmetrikus” nézetet a világról, hogy csak a tudományos ismeretek tekinthetőek racionálisnak, míg a tankönyvekben sok esetben már nem, vagy még nem szereplő tudás pedig irracionálisnak? Hogyan lehet a népi tudást átadni annak a célközönségnek (tanulók, szaktanácsadók stb.), akik a tudományosan megalapozott ismeretek elfogadásához és megtanulásához vannak hozzászokva? Hogyan tudjuk a tudományos megközelítést kombinálni a népi tudással? Milyen pedagógiai módszerek teszik lehetővé az informális tudás átadását? A hagyományos agroökológai ismeretek „birtoklói” hogyan szerezték meg tudásukat? Képzésekbe ágyazva hogyan lehetne ezeket a tapasztalaton alapuló ismereteket továbbadni? Az agroökológiai ismeretek oktatása számos európai országban MSc szinten is megjelenik, országonként változó program elnevezéssel (Angliában pl. Agroökológia és Élelmiszerbiztonság; Norvégiában Agroökológia; Franciaországban és Szlovéniában Agroökológia és Ökológiai gazdálkodás stb.), de az igény az informális ismeretek hatékonyabb képzésbe ágyazására a már meglévő programokkal rendelkező országokban is megmutatkozik (Francis et al. 2011).

A SAGITER projekt magyar résztvevői különös figyelmet szentelnek az ökológiai gazdálkodásnak, hiszen ez az egyik legjobb példája az agroökológiai szemléletü gazdálkodásnak, és más gazdálkodási rendszerektől eltérően (pl. permakultúra, mezőgazdasági erdészet) kidolgozott tanúsítási rendszerrel rendelkezik. Ebből következik, hogy a szigorú szabályokat betartó ökológiai gazdálkodási rendszer könnyebben nyomon követhető, következetes, és mint rendszer jobban vizsgálható projekt szinten is.

Ezen túlmenően az ökológiai gazdálkodás alapelvei a mezőgazdaság legtágabb értelmezésére vonatkoznak. Ebbe az is beletartozik, hogy az emberek hogyan viselik gondját a természeti erőforrásoknak (pl. földnek, víznek, levegőnek), a növényeknek és az állatoknak, hogyan kerülnek kapcsolatba az éló tájjal és egymással, hogyan formálják a jövő generációjának örökségét.

Erre alapozva az ökológiai gazdálkodás négy alapelvét az IFOAM (International Federation of Organic Agriculture Movements 1972) így fogalmazza meg:

Környezet megóvásának alapelve: A mezőgazdasági termelés jelentős mértékben használja a természeti erőforrásokat, így kihat annak állapotára, minőségére akkor is, ha azt csak kis területen, kis volumenben végezzük. A gazdálkodásnak ökológiai rendszereken és biológiai ciklusokon kell alapulnia, és az élő ökológiai rendszerekbe ágyazva, azokat fenntartva kell müködnie. A termelési rendszer kialakításának és irányításának illeszkednie szükséges a természet ökológiai rend- 
szeréhez, a helyi lehetőségekhez és kultúrához. Az ökológiai gazdálkodás során előnyben kell részesíteni közös környezetünk, a táj, klíma, levegö, víz és a diverzitás védelmét, a talaj-növény-állat-ember kölcsönhatásában való gondolkodást. A környezet fenntartása és az erőforrások megőrzése érdekében csökkenteni kell az inputot újrahasznosítással és hatékony anyag- és energiagazdálkodással.

Méltányosság alapelve: Fontos a tisztelet, az igazságosság és a gondoskodás az emberek, valamint az ember és más élölények közötti kapcsolatokban. Az ökológiai gazdálkodásban résztvevőknek úgy kell irányítaniuk az emberi kapcsolatokat, hogy azok biztosítsák a 'fair play'-t vagyis a sportszerüséget minden szinten és minden csoportnak, a gazdálkodóktól a fogyasztókig.

Az ökogazdálkodásnak elegendő mennyiségü és jó minőségü, egészséges élelmiszert kell termelnie, hozzá kell járulnia az élelmiszer elosztásához és a szegénység csökkentéséhez. Az állatokat természetes viselkedésüknek és jóllétüknek megfelelően kell tartani és ellátni. Ez olyan termelési-elosztási-kereskedelmi rendszereket igényel, amelyek méltányosak, igazságosak, és a valódi társadalmi és szociális környezet költség-haszon összefüggéseire visszavezethetőek. A jövő generációjára nézve felelősen kell bánni a környezeti erőforrásokkal, igénybevételük során figyelembe kell venni az ökológiai és szociális szempontokat.

Gondosság alapelve: A gazdálkodás során a „nem ártani” elvet kell alkalmazni. Az ökogazdaságot felelősen kell irányítani, hogy megvédjük a jelen és a jövő generáció egészségét, jóllétét és környezetét. Az ökológiai gazdálkodás egy élő és dinamikus rendszer, mely a belső és külső igényekre válaszol. Az ökológiai gazdálkodás hatékonysága, termelékenysége növelhetö, de az nem veszélyeztetheti a jóllétet és az egészséget. Az új alkalmazandó technológiákat ellenőrizni kell és a meglévő módszereket felül kell vizsgálni. A tudományos tudás azonban önmagában nem hatékony, szükség van a gyakorlati tapasztalatra, az előző generációk bölcsességre, a hagyományos tudásra, amit az idő már igazolt. Az ökológiai gazdálkodásnak meg kell előznie a termelésből adódó jelentős kockázatot azzal, hogy a megfelelö technológiákat alkalmazza és elutasítja a megjósolhatatlan kimenetelüeket.

Egészség alapelve: Az egészség minél szélesebb körü értelmezése szükséges. Az ökológiai gazdálkodásnak fent kell tartania és erősítenie a talaj-növény-állatélelmiszer-ember - és ezzel az egész környezet és a Föld - egészségét, ezeket egyként és egymástól elválaszthatatlanul kezelve. Az egyén és a közösség egészsége nem választható szét az ökoszisztémák egészségétől. Az élő rendszer egészsége nemcsak a betegség hiányát jelenti, hanem a fizikai, mentális, szociális és ökológiai jóllét fenntartását. A biogazdálkodás szerepe, hogy a teljes gazdálkodás során fenntartsa és erősítse az ökoszisztémák és minden szervezet egészségét a talajban élő élőlényektől az emberig. Az ökológiai gazdálkodásban fontos a magas minő- 
ségü és egészséges élelmiszer előállítása, ami hozzájárul a preventív egészséggondozáshoz.

A projekt keretén belül az ökológiai gazdálkodás alapelveit figyelembe véve mértük fel a magyar hallgatók ismereteit, hogy az eredmények kiértékelése után olyan képzési palettát kínáljunk, amely az esetleges hiányosságokat pótolja. Ezeket a kidolgozott oktatási modulokat a 2016 szeptemberére elkészülő pedagógiai módszertani segédlet legmegfelelőbb módszertanával fogjuk összepárosítani.

\section{Módszerek}

A projekt 3 éves futamideje alatt (2014-2016) a lehetö legeredményesebb munka érdekében 7 európai ország (Franciaország, Németország, Szlovénia, Románia, Magyarország, Belgium, Spanyolország) 11 intézetének (felsőoktatási intézmény, agrártovábbképző központ, kamara, civil szervezet) munkatársai dolgoznak együtt.

A tudásátadás komplexitásából adódóan magyarországi kutatómunkánk első lépéseként beazonosítottuk, hogy milyen alapismeretekkel rendelkezik a célcsoport agroökológia témakörben. Ennek megfelelően 2014-ben felmérést végeztünk, hogy megismerjük az egyetemi hallgatók véleményét és azonosítsuk a tudásszintjét. A felmérésben 258 hallgató vett részt, 215 hallgató a Szent István Egyetemről, míg 43 hallgató a Debreceni Egyetemről.

A válaszadók BSc, BA (alapképzés) és MSc (mesterképzés) hallgatók voltak két egyetemi karról: a Mezőgazdaság- és Környezettudományi Karról (Állattenyésztő mérnök BSc és MSc hallgatók; Növénytermesztő mérnök BSc és MSc hallgatók, valamint Környezetgazdálkodási agrármérnök MSc hallgatók), illetve a Gazdaság- és Társadalomtudományi Karról (Gazdálkodási és menedzsment BA; Gazdasági és vidékfejlesztési agrármérnök BSc, valamint Marketing MSc hallgatók). „Agroökológia” elnevezésü tantárgyat egyik válaszadó sem hallgatott a válaszadás időpontja előtt, de a Mezőgazdaság- és Környezettudományi Kar hallgatói jellemzően hallgattak már korábban agroökológiai ismereteket is magukba foglaló tantárgyakat, ahol az agroökológia résztémaként jelent meg (pl. agrár-környezetgazdálkodási rendszerek; földmüveléstan alapjai; környezetgazdálkodás; tájökológia stb.). A Gazdaság- és Társadalomtudományi Kar válaszadó hallgatói nem rendelkeztek a felmérés időpontjában előzetes agroökológiai ismeretekkel. A válaszadók az ökológiai gazdálkodási ismereteket választható tantárgyak keretén belül sajátíthatták el, vagy egyes tantárgyak résztémájaként ismerhették meg. 
A felmérésben résztvevők képzési szintjéröl, évfolyam szintjéről, egyetemi kar szerinti eloszlásáról, valamint a válaszadók neméről az 1. táblázat nyújt tájékoztatást.

1. táblázat. A felmérésben résztvevők képzési szintjének, évfolyamának, egyetemi karnak, valamint nemének eloszlása.

\begin{tabular}{ccc}
\hline \multirow{2}{*}{ képzési szint } & BSc, BA & $67,80 \%$ \\
& MSc & $32,20 \%$ \\
\hline \multirow{2}{*}{ évfolyam } & I. & $17,40 \%$ \\
& II. & $19,80 \%$ \\
& III. & $30,60 \%$ \\
& IV. & $15,10 \%$ \\
egyetemi kar & V. & $17,10 \%$ \\
\hline \multirow{2}{*}{ nemek } & Mezőgazdaság- és Környezettudományi Kar & $52,30 \%$ \\
& Gazdaság- és társadalomtudományi Kar & $47,70 \%$ \\
\hline & férfi & $38,40 \%$ \\
& nő & $61,60 \%$ \\
\hline
\end{tabular}

A kérdőív 4 típusú kérdést tartalmazott:

- $\quad$ egyszeres választás

- $\quad$ többszörös választás (több lehetséges válasszal)

- $\quad$ értékelö skála

- nyitott kérdés

A kérdőív három fö részből tevődött össze, a fenntartható mezőgazdaságra, környezetvédelem témájára és az ökológiai gazdálkodásra fókuszálva.

A kérdőívek eredményei közül az ökológiai gazdálkodásra vonatkozó kérdések elemzésével foglalkozunk jelen írásban. A válaszok kiértékelése tükrében állítottuk össze képzési tervünket, amelyek különböző pedagógiai módszerekkel hivatottak a hagyományos agroökológiai ismeretek átadására egy-egy speciális témára fókuszálva (lásd megvitatás). A kérdőív ökológiai gazdálkodásra vonatkozó kérdései a következők:

- Véleménye szerint az alábbi állítások mennyire azonosíthatóak az ökológiai gazdálkodás alapelveivel? 1-egyáltalán nem, 5-teljes mértékben. A köztes értékekkel árnyalhatja véleményét! (A lehetséges válaszokat (állításokat) az eredmények kiértékelése során a 2. és 3. táblázat szemlélteti.)

- Kérem, jelölje meg azokat a tényezőket, melyeket véleménye szerint szükséges figyelembe venni az ökológiai gazdálkodás kialakításakor! (több válasz bejelölhető!) (A lehetséges válaszokat (tényezőket) az eredmények kiértékelése során az 1. ábra szemlélteti.) 
2. táblázat. Biogazdálkodás alapelveinek ismeretét felmérő kérdőív eredménye. (mintaszám=258)

\begin{tabular}{|c|c|c|}
\hline Biogazdálkodás alapelvei & Átlag & Szórás \\
\hline $\begin{array}{l}\text { A talajtermékenységfokozására és fenntartására törekszik hosszú- } \\
\text { távon }\end{array}$ & 4,43 & 0,82 \\
\hline $\begin{array}{l}\text { Szerves anyagok körforgását elősegíti és támogatja a termelési rend- } \\
\text { szeren belül }\end{array}$ & 4,25 & 0,85 \\
\hline $\begin{array}{l}\text { Mezőgazdasági gépek környezetszennyezésének minimalizálására } \\
\text { törekszik }\end{array}$ & 4,21 & 0,97 \\
\hline Természettel összhangban történik a gazdálkodás & 4,19 & 0,91 \\
\hline $\begin{array}{l}\text { Mezőgazdálkodás által érintett területek genetikai sokféleségének } \\
\text { fenntartására törekszik, a növények és állatok természetes élőhelyét } \\
\text { megőrzi }\end{array}$ & 4,15 & 0,85 \\
\hline Állatjóléti szempontokat figyelembe veszi & 4,04 & 0,89 \\
\hline $\begin{array}{l}\text { A megújuló energiaforrásokat maximálisan kihasználja a helyi } \\
\text { mezőgazdálkodásban }\end{array}$ & 4,01 & 1,01 \\
\hline $\begin{array}{l}\text { Mezőgazdasági termények feldolgozása során megújuló energia- } \\
\text { forrásokat használ }\end{array}$ & 3,98 & 0,9 \\
\hline $\begin{array}{l}\text { Zárt rendszeren belül gondolkodik, beleértve a szerves anyagok } \\
\text { felhasználását és a feldolgozott élelmiszer összetevőket is }\end{array}$ & 3,91 & 0,9 \\
\hline $\begin{array}{l}\text { Figyelembe veszi a gazdálkodás szélesebb körben eredményezett } \\
\text { társadalmi és ökológiai hatásait is }\end{array}$ & 3,85 & 0,91 \\
\hline Magas tápértékű élelmiszereket állít elő & 3,8 & 0,99 \\
\hline $\begin{array}{l}\text { Ellenálló fajták használatára törekszik a biolalapanyagok előállítása } \\
\text { során }\end{array}$ & 3,61 & 0,99 \\
\hline $\begin{array}{l}\text { A gazdaság alkalmazottai elfogadható fizetést kapnak. Biztonságosak } \\
\text { a munkakörülmények }\end{array}$ & 3,32 & 1,04 \\
\hline Jó minőségű és tartós textilalapanyagokat állít elő & 3,2 & 0,99 \\
\hline
\end{tabular}

3. táblázat. MSc és BSc hallgatók válaszaiban szignifikáns különbséget mutató kérdések.

\begin{tabular}{lccc}
\hline Biogazdálkodási alapelv & \multicolumn{2}{c}{ Átlag } & \multirow{2}{*}{ p-érték } \\
\hline $\begin{array}{l}\text { Figyelembe veszi a gazdálkodás szélesebb körben ered- } \\
\text { ményezett társadalmi és ökológiai hatásait is }\end{array}$ & 3,70 & 4,16 & $<0,001$ \\
$\begin{array}{l}\text { Mezőgazdálkodás által érintett területek genetikai } \\
\text { sokféleségének fenntartására törekszik, a növények és }\end{array}$ & 4,06 & 4,33 & 0,018 \\
$\begin{array}{l}\text { állatok természetes élőhelyét megőrzi } \\
\begin{array}{l}\text { Mezőgazdasági gépek környezetszennyezésének mini- } \\
\text { malizálására törekszik }\end{array}\end{array}$ & 4,12 & 4,40 & 0,021 \\
$\begin{array}{l}\text { A megújuló energiaforrásokat maximálisan kihasználja a } \\
\text { helyi mezőgazdálkodásban }\end{array}$ & 3,91 & 4,22 & 0,021 \\
\hline
\end{tabular}




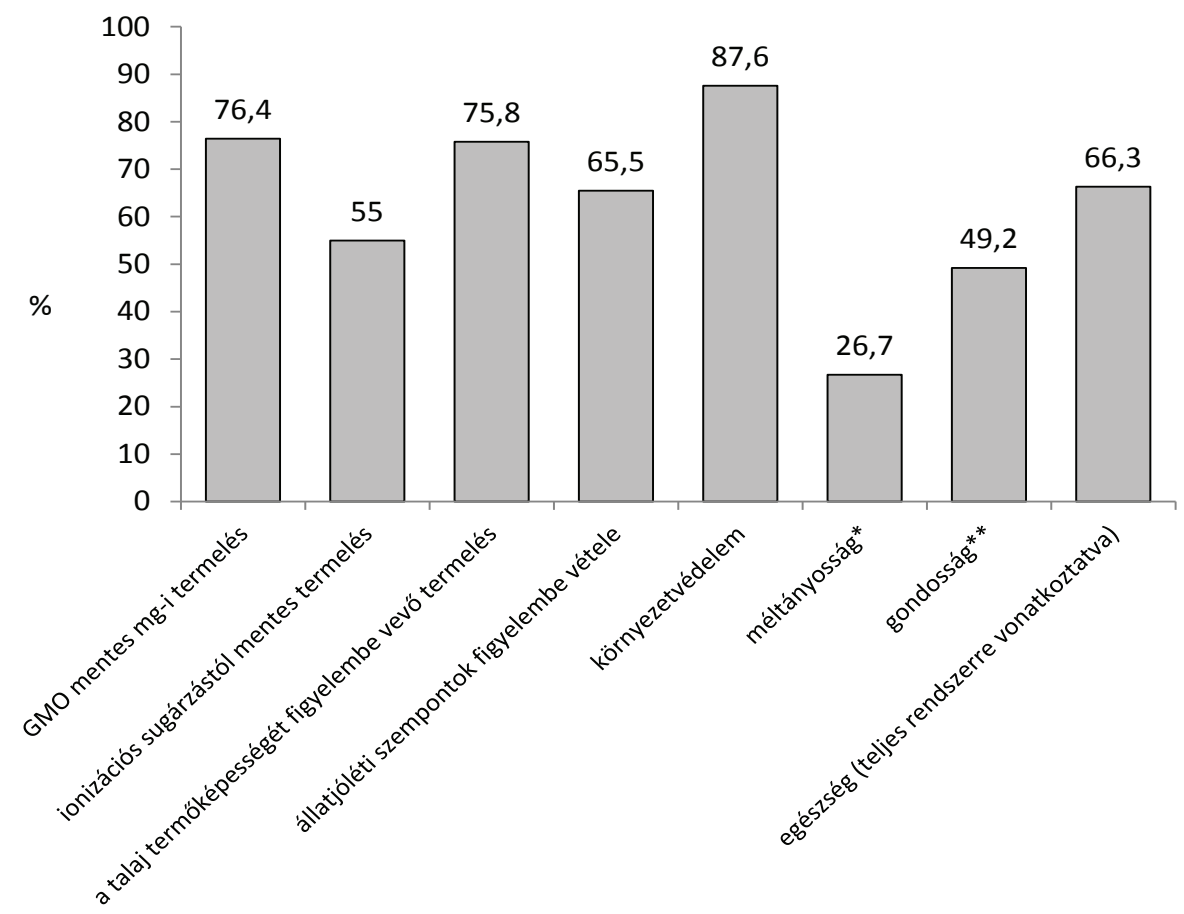

1. ábra. : Ökogazdaság kialakítása és működtetése során figyelembeveendő tényezők *(teljes rendszerre vonatkoztatva pl. üzleti partnerekkel, jövő generációjával) **(felelősség, figyelem pl. új technológiák bevezetése során) mintaszám=258

4. táblázat. : Ökogazdaságok létrehozását és müködtetését nehezítő tényezők. *Pl. Korábbi szermaradványok jelenléte; **Pl. utaktól való távolság; mintaszám=258

\begin{tabular}{ccc}
\hline Nehezítő tényezők & Átlag & Szórás \\
\hline $\begin{array}{c}\text { Jogi szabályozás hiányosságai } \\
\text { A gazdálkodás területén már meglévő káros anyagok* }\end{array}$ & 3,68 & 0,92 \\
$\begin{array}{c}\text { Egyéb szennyezést okozó forrásoktól való távolság szabályozásának } \\
\text { hiányossága** }\end{array}$ & 3,42 & 0,75 \\
A környező földekről származó szennyeződések elkerülhetetlenek & 4,09 & 0,85 \\
A környezetböl származó káros hatások & 4,08 & 0,81 \\
\hline
\end{tabular}


- Véleménye szerint az alábbi tényezők mennyire veszélyeztetik az ökológiai gazdaságok létrehozását? (1-egyáltalán nem, 5-teljes mértékben; a köztes értékekkel árnyalhatja véleményét) (A lehetséges válaszokat (tényezőket) az eredmények kiértékelése során a 4. táblázat szemlélteti.)

Az eredmények ismertetésénél a kérdőív konkrét kérdésére ismét kitérünk, a többszörös választás vagy értékelő skálás típusú kérdésnél a lehetséges válaszokat szemléltetjük az ábra és táblázatok segítségével. A kérdőív statisztikai elemzését kétmintás t-próba és egyszempontos varianciaanalízis segítségével végeztük.

\section{Eredmények}

Az ökológiai gazdálkodás az egyik legjobb mintája a fenntartható agroökológiai rendszernek, ezért a kérdőív a célcsoport véleményét nagyban tükrözi az agroökológia gyakorlatáról, valamint feltárja tudásszintjüket is. A hallgatókat arra kértük, hogy értékeljék a felsorolt állításokat (lásd 2. táblázat) aszerint, hogy megítélésük szerint mennyire igazak az ökológiai gazdálkodás alapelveire és gyakorlatára. A 2. táblázat szemlélteti a kapott eredményeket. Megfigyelhető, hogy az állítások súlyozása során környezetvédelmi kérdésekben erősnek találják az ökológiai gazdálkodást (átlag 4,0 felett van), míg az ökológiai gazdálkodás részét képező konkrét tevékenységek és az ökológiai gazdálkodás szociális pillérének kevésbé tulajdonítanak nagy jelentőséget (Pl. megújuló energia használata, ökológiai gazdálkodás társadalmi hatása). Ez eredhet abból, hogy a gazdálkodásra jellemző szellemiség és az ebből adódó tevékenységek, amelyek a fenntarthatóságot célozzák, nem teljesen ismertek a hallgatók körében. A magas szórás azonban arra enged következtetni, hogy az egyes kijelentések értékelése során, a célcsoport tagjai az ökológiai gazdálkodás elemeit különbözőképpen ítélik meg. Ez adódik abból, hogy a célcsoport tagjai különböző egyetemi karokon és eltérő évfolyamon tanulnak. Jellemzően a mesterszakos hallgatók ismerik fel jobban az összefüggéseket az ökogazdálkodás alapelvei és gyakorlata között. A statisztikai kiértékelés során a szórások között nem volt kimutatható szignifikáns különbség, ezért lehetővé vált a kétmintás t-próba alkalmazása. Több kérdés esetén is szignifikáns különbséget találtunk 95\%-os megbízhatósági szinten $(\mathrm{p}<0,05)$ a mesterszakos és alapszakos hallgatók válaszai között (3. táblázat). A mesterszakos hallgatók vélik úgy, hogy a megújuló energiaforrások maximális kihasználása (átlag alapszakos hallgatóknál: 3,91; mesterszakos hallgatóknál: 4,22; p-érték: 0,021), a káros anyag kibocsátásának minimalizálása (átlag alapszakos hallgatóknál: 4,12; mesterszakos hallgatóknál: 4,40; p-érték:0,021), a megmüvelt területek genetikai sokszínűségének megőrzése és az élőhelyek védelme (átlag alapszakos hallgatóknál: 4,06; mesterszakos hallgatóknál: 4,33; p-érték: 0,018), hozzájárul a sikeres 
ökogazdaság müködtetéséhez. Továbbá szintén a mesterszakos hallgatók $(4,16)$ azok (4. évfolyam 4,23; 5. évfolyam 4,10), akik meglátják a szélesebb összefüggéseket, és az ökológiai gazdálkodás társadalmi vonatkozásait is felismerik (p-érték: 0,000).

Varianciaanalízisünk 95\%-os konfidenciával azt támasztja alá, hogy a másodéves hallgatók többsége úgy véli, a zárt rendszeren belüli gondolkodás, amibe a szervesanyag-forgalom és a kész termékek alapanyagainak az elóállítása is beletartozik, fontos alapeleme az ökológiai gazdálkodásnak (átlag: 4,12 p-érték: 0,029). Az első éves hallgatók erről még másképp vélekednek, esetükben átlagosan csak 3,32-nek és 3,63-nak felel meg ez az állítás az ötös skálán. Mindezek mellett a biztonságos munkakörülményeket és az elfogadható fizetést az Mezőgazdaság- és Környezettudományi Kar hallgatói tartják az ökológiai gazdálkodás alapelveivel beazonosíthatónak (átlag: 3,46; kétmintás t-próba p-értéke: 0,016).

Megállapítható, hogy a környezettudatos oktatási struktúra hatással van a válaszadók szemléletformálására és természetesen a háttértudásuk szintjére is, de csak a többed éves hallgatók (MSc képzésben részt vevők) ismerik fel a konkrét tevékenységeket, amelyek hozzájárulnak egy biogazdaság fenntarthatóságához. Ez a magyarázata annak, hogy a varianciaanalízis során a „gazdálkodás szélesebb körben eredményezett társadalmi és ökológiai hatásának" értékelése során szignifikáns eltérést találtunk a különböző évfolyamok válaszadóinak válaszai között (p-érték: 0,004).

Az 1. ábra szemlélteti a hallgatók arra a kérdésre adott válaszait, hogy véleményük szerint melyek azok a tényezők, melyeket feltétlen figyelembe kell venni egy ökogazdaság megtervezése és múködtetési kereteinek kialakítása során. A válaszadók több kritériumot is jelölhettek. Az 1. ábrán jól látható, hogy mindegyik állítást fontosnak tartják a hallgatók, a „méltányosság” azonban csak 26,7\%-ot ért el, ami szintén arra utal, hogy az ökológiai gazdálkodás társadalmi vonatkozásait nem tartják fontosnak, vagy inkább az ökológiai gazdálkodásra vonatkoztatva a méltányosság fogalma mögötti tartalmat a hallhatók nem ismerik. Az ökológiai gazdálkodás 4 alapelve (IFOAM 1972) közül a méltányosságot és a gondosságot tartják a legkevésbé fontosnak. Ezzel szemben a környezetvédelem kiemelt helyen végzett, és az egészség is a hallgatók válaszai alapján 66,3\%-ban fontos kritérium az ökológiai gazdálkodás gyakorlatában. A válaszok összesítéséből jól tükröződik, hogy a felmérésben résztvevők háttérismeretei hiányosak, az ökológiai gazdálkodásnak csak részterületeit ismerik, hiányzik a holisztikus megközelítés, a hosszú távú hatását és sok esetben a kézzel nem fogható hatását nem ismerik. Az ökológiai gazdálkodásnak elsősorban a rövidtávon is eredményes résztevékenységeit tartják fontosnak. Érdekes megfigyelni, hogy a nők és férfiak hogyan vélekednek a méltányosság, a gondosság és az egészség fogalmáról az 
ökológiai gazdálkodás kontextusában. A férfiak megítélése szerint ezek az alapelvek fontosabbak, mint a nők szerint. 39,4\%-uk szerint a méltányosság, 60,6\%-uk szerint a gondosság, míg 73,7\%-uk szerint pedig az egészség sarkalatos pontja a biogazdálkodásnak. Az ábrából az is kitünik, hogy az ökológiai gazdálkodásra jellemző, de inkább általánosabb, ismertebb fogalmakat tartották egyértelmüen beazonosíthatónak az ökológiai gazdálkodás kritériumai közül a megkérdezettek (GMO mentesség, környezetvédelem, talaj termöképesség).

A harmadik kérdéscsoportban arra voltunk kíváncsiak, hogy a célcsoport szerint melyek azok a tényezők, amelyek veszélyeztethetik, kockázatként jelentkeznek egy ökológiai gazdaság létrehozása és müködtetése során. Dezsény és Drexler tanulmánya (2012) szerint a legtöbb esetben a gazdálkodók nagyon kritikusak és szkeptikusak az ökológiai gazdálkodással szemben, ami miatt a 4. táblázatban felsorakoztatott esetleges problémák, és azoknak nehézkes megoldási lehetőségei is okolhatóak. A megkérdezettek szintén úgy vélik, hogy a külső környezeti negatív hatások veszélyeztethetik az ökogazdaságot. A jogi szabályozás hiányosságait kevésbé tartják akadályozó tényezőnek.

Érdekes megfigyelni, hogy a női válaszadók eltérően súlyozták a környezetből származó káros hatásokat, sokkal inkább kockázatosnak ítélték meg a férfiakkal ellentétben (2. ábra). A környezetből származó káros hatások kérdésre adott válaszok között szignifikáns eltérést találtunk a kétmintás t-próba alkalmazása során (95\%-os megbízhatósági szint mellett $\mathrm{p}=0,003$ ).

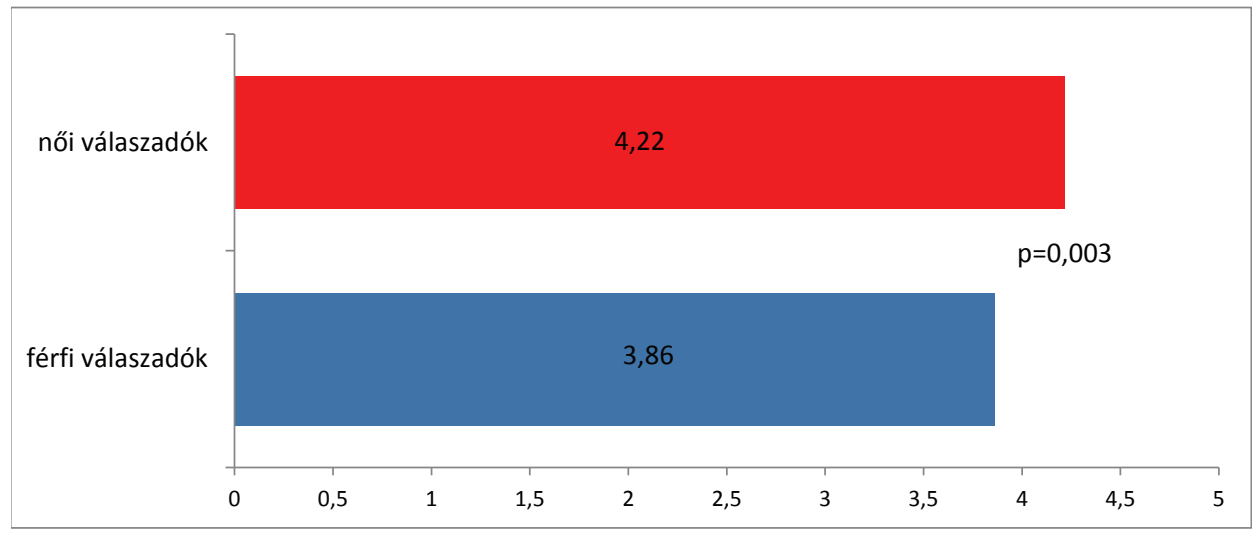

2. ábra. : A környezetből származó káros hatások megítélése a válaszadók neme alapján. $p<0,05$ 


\section{Értékelés}

Általánosságban megfogalmazható, hogy az agroökológiai rendszereken belül az ökológiai gazdálkodást a hallgatók ismerik, nehézségeit, gyengeségeit be tudják azonosítani. A konkrét esettanulmányok megismerése, ökogazdaságok szakmai látogatása az ismereteket bővíthetik és elmélyíthetik, hiszen konkrét példákon keresztül könnyebben érzékelhető és elsajátítható az agroökológia elveinek gyakorlatban történő megvalósítása.

A felmérésünk eredményei alapján azonban az is megállapítható, hogy a hallgatók ökológiai gazdálkodással kapcsolatos háttérismerete nagyon változó. A környezetvédelemhez kapcsolódó tantárgyakat már lehallgatott mesterképzésben részt vevő hallgatók ismerete megalapozottabb, az összefüggéseket jobban felismerik. Összességében az ökogazdálkodás környezetre gyakorolt hatását felismerik, pozitívan értékelik, azonban nem látják hosszú távú, más területeket, más dimenziót érintő hatását, mint pl. a társadalomra és gazdaságra kivetített hatását. A nemzetközi tapasztalatok is erről számolnak be (Francis et al. 2011).

Eredményeink Dover és Talbot már 1978-ban leírt megállapításával is párhuzamba állítható, miszerint az ökológiai szemléletủ mezőgazdaság eltér az ipari mezőgazdálkodástól, mely utóbbi évtizedek óta uralja a mezőgazdasági kutatásokat, fejlesztéseket, és az oktatás alapjául is szolgál. Francis et al. (2013) is hangsúlyozza, hogy sajnálatos módon a mezőgazdasági képzések nagy része az utóbbi időben inkább az elméletre fókuszál formális tanulási környezetben (osztályterem, előadó), míg a gyakorlati oktatás egyre inkább háttérbe szorul. Dover és Talbot (1978), Francis et al. (2011), valamint a SARE kiadványának szakemberei (2010) hozzánk hasonlóan abban látják a megoldást, ha a fenntartható mezőgazdálkodás iránti elköteleződés egy olyan stratégia részévé válik, ahol az új generáció képzése már az ökológiai szemléletü kutatási eredményeken alapszik. Ennek megfelelően multidiszciplináris, átfogó ökológiai mezőgazdasági képzésekre van szükség a mezőgazdasági szakközépiskolákban és egyetemeken, hogy olyan jövőbeli agroökológusokat képezzünk, akik képesek teljes rendszerben gondolkodni, és olyan agroökológiai kérdésekben állást foglalni, amelyek a döntéshozók intézkedéseit szakmailag megalapozzák. Ezek ismeretében javaslataink a következők: Az agroökológia számos szegmensét, az ökológiai gazdálkodáshoz hasonlóan (ami már önálló tantárgyként, szakirányként, vagy MSc programként megjelenik) érdemes lenne jobban beépíteni a BSc és MSc képzésekbe, a következőket is figyelembe véve:

- Komplexitás - A környezetvédelmen túlmenően az agroökológia szociális és gazdasági pillérét, céljait, hatását is tanítani kell.

- Nyomon követhetőség - A komplexitás mellett a hallgatóknak fel kell ismerniük, hogy miért van szükséges az ökológiai gazdálkodás rendszerében 
az ellenőrzésre és tanúsításra, ami a biotermékek szélesebb körben történő elterjedését, és a fogyasztók bizalmának megerősödését is szolgálja.

- Szociális érzékenység - az ökológiai gazdálkodásban a méltányosság alapelvként jelenik meg. A méltányosság mögötti tartalom más agroökológiai rendszerekben is ugyanúgy érvényesülhet, és kellene is érvényesülnie. Az oktatók jövőbeli feladata, hogy bemutassák már a BSc hallgatóknak is az agroökológia közjóléti szerepét.

- A hallgatók tudásszintbeli különbségét tompítani lehetne, ha a gazdasági tanulmányokat végzö hallgatók is több ökológiához kapcsolt témával ismerkednének meg, míg az alapképzésben részt vevő hallgatók több gyakorlat-orientált oktatásban részesülnének (farmlátogatás, esettanulmányok), hogy a gazdasági tantárgyak ellensúlyozásaként gyakorlatban is lássanak olyan müködő gazdaságokat, amelyek a profittermelésen túlmenően a szociális és környezetkímélő szempontokat is szem előtt tartják.

- Felmérésünkből az is kitünik, hogy a férfi válaszadók több mezőgazdasági tapasztalattal rendelkeznek. Érdemes lenne fontolóra venni, hogy a nőket hogyan lehetne jobban bevonni a gyakorlatiasabb mezőgazdasági tevékenységekbe, hogy komplexebben lássák a termelési rendszert.

- A tudásátadás módszerei közül a tapasztalva tanulást kell elötérbe helyezni. Köztudottan az egyik legjobb módszer a tudás elsajátítására. Østergaard és társai (2010) kutatásai azt is hangsúlyozzák, hogy a gyakorlatszerzés és elméleti tudás megszerzésének sorrendje sem mindegy. A tapasztalatra épülö elméleti tudás sokkal megalapozottabbá teszi a tanulók ismereteit. Magyarországon, ennek mintájára, a BSc és az MSc szinten is az elméleti oktatás mellett a gyakorlati oktatásnak is hangsúlyosan kellene megjelennie, hiszen csak így lehet hatékonyan képezni tudatosan gondolkodó, gyakorlatban elhelyezkedő szakembereket.

Javaslataink alapján a SAGITER projekt keretén belül a magyar hallgatóknak egy olyan képzési palettát állítottunk össze, amely lefedi az agroökológia azon területeit, amelyek esetében ismerethiányt tapasztaltunk a felmérés során. Ezeknek a moduloknak a témáit az 5. táblázat ismerteti.

A modulkínálatból kiemelve egy-egy téma külön is megállja a helyét, hiszen tudatosan szerepel benne gyakorlatra alapozott, kiscsoportban müködő, speciális oktatási módszert (pl. gondolattérkép készítés, CLIM módszer) beemelő modul, illetve előadóteremben is ismertethető téma.

Bár egyetlen projekt keretén belül nem lehet megváltoztatni a felsőoktatási rendszer struktúráját, de hisszük, hogy a projekt végére az oktatóknak elkészített módszertani tudástár, jógyakorlat-gyüjtemény segítségünkre lesz, hogy az agroökológia fontos elemeit minél hatékonyabban át tudjuk adni a hallgatóknak. A szélesebb összefüggések felismerése (pl. szélsőséges vízháztartási jelenségek, szénforgalom szabályozás, stb.) miatt elengedhetetlenné válik az agroökológiai 
5. táblázat. A Szent István Egyetem munkatársainak modul összeállítása az agroökológiai ismeretek hatékonyabb elsajátítása céljából.

\begin{tabular}{l}
\hline \multicolumn{1}{c}{ Modul címe } \\
\hline Fenntartható mezőgazdaság föbb \\
tényezöi, értékelési rendsze- \\
re, valamint megismerésének \\
módszerei \\
Agroökológiai ismeretek és alkal- \\
mazásuk az ökológiai gazdálko- \\
dásban \\
Agroökológiai gazdálkodás gya- \\
korlati tapasztalatai a Zsámboki \\
Biokertészetben
\end{tabular}

Hagyományos ökológiai ismeretek átadása és lehetséges használatuk a természeti erőforrások megőrzésében, használatában

Nemzeti park igazgatóságok szerepe az ökológiai szemlélet megismertetésében és formálásában

Fenntarthatóság és szemléletének alapvető szempontjai és jövője (termelés, feldolgozás, értékesítés, egészség, élelmiszerpazarlás, klímaváltozás, háztartásvezetési gyakorlatok)

Pedagógiai módszerek és alkalmazásuk az agroökológiai tudásátadásban

Ökológiai szemlélet alkalmazásának lehetőségei az élelmiszerellátási rendszerekben (tömegáru, helyi termék, stb. az alternatív értékesítés területén)
Modul leírása

A fenntartható mezőgazdaság céljai, szemléleti és szakmai háttere, módszereinek előnyei a gazdaság, a társadalom és a környezet szempontjából.

Ökológiai gazdálkodás alapelvei, rendszerszemléletének alapjai. Az agroökológia elemeinek felismerése és alkalmazása az ökológiai gazdálkodásban: talajtermékenység fenntartása, vetésforgó, talajvédő művelés, talajtakarás, komposztálás, vegyszermentes gyomszabályozás. Ökológiai gazdálkodás szociális és társadalmi aspektusai.

Az ökológiai zöldségtermesztés praktikáinak megismerése és elsajátítása gyakorlaton keresztül. A cél a kisléptékü gazdaság szezonális tevékenységeiben való aktív részvétel, holisztikus tapasztalatszerzés (pl. korai tavaszi vetés, kiültetés, késő tavaszi kiültetés, kapálás, növényápolás, komposztálás). Szociális farm múködése a gyakorlatban.

A pásztortudomány tanulási módjai lényegesen eltérnek a ma megszokott oktatási rendszertől. Elsősorban idősektől, és maguktól (tapasztalatból) tanulnak, de fontos a jószágtól és a tájtól való tanulás is.

A hazai nemzeti park igazgatóságok rövid bemutatása, különös tekintettel a mezögazdálkodást folytatókra: legeltetéses állattartás és kaszálásos rétgazdálkodás, kisparcellás szántóföldi mủvelés, extenzív kisparaszti gyümölcsösök.

A fenntarthatóság főbb összefüggései, a mezőgazdasági termelés technológiai fejlődése és alkalmazott innovációk. Családi gazdaságok fejlődésének trendjei, termékpályák szereplői és funkciói. Élelmiszer ellátás biztonsága, pazarlás és háztartás vezetés.

Közvetlen pedagógiai és kommunikációs eszköztár megismerése a fenntartható, ökológiailag kiegyensúlyozottabb életvitel/gazdasági magatartás elérésért. Pszichológiai és közgazdaságtani elméletek, melyek megismerése támogatja a saját és közösségünk tudatosabb és egészségesebb életvitelre való átállását. A modul gyakorlati részében a meggyőzés illetve a hatékony előadás technikáit sajátíthatják el a hallgatók.

Élelmiszer ellátási rendszerek kialakulása, alternatív módszerek és eszközök. Helyi termékek és hagyományos és tájfajták szerepe és fenntartható élelmiszertermelésben. Hogyan értékeljük a fenntartható mezőgazdaságot? Hallgatói prezentációk és példák bemutatása, értékelése. 
5. táblázat (folytatás). A Szent István Egyetem munkatársainak modul összeállítása az agroökológiai ismeretek hatékonyabb elsajátítása céljából.

\begin{tabular}{|c|c|}
\hline Modul címe & Modul leírása \\
\hline $\begin{array}{l}\text { Az agroökológiai adottságokhoz } \\
\text { alkalmazkodó gazdálkodás történeti } \\
\text { példái és szükségessége napjainkban }\end{array}$ & $\begin{array}{l}\text { A modul célja: } \\
\text { 1. rövid, tömör áttekintést nyújtani a hagyományos, } \\
\text { környezeti adottságokhoz alkalmazkodó sík-, domb- } \\
\text { és hegyvidéki gazdálkodási formákról és tájhaszná- } \\
\text { latról; } \\
\text { 2. bepillantást nyújtani a Kárpát-medence képét és } \\
\text { gazdálkodását gyökeresen megváltoztató tevékenysé- } \\
\text { gekbe, folyamatokba; } \\
\text { 3. rávilágítani a gazdálkodás környezethez való alkal- } \\
\text { mazkodásának mai szükségszerüségére. }\end{array}$ \\
\hline Agrohomeopátia & $\begin{array}{l}\text { Agrohomeopátiás készítmények általános bemuta- } \\
\text { tása; innovatív megoldási lehetőségei a peszticidek } \\
\text { helyettesítésére; készítmények hatásmechanizmus; } \\
\text { alkalmazási területük ismertetése a mezőgazdaság- } \\
\text { ban, kertészetben, dísznövénykertészetben. } \\
\text { Jó gyakorlatok ismertetése }\end{array}$ \\
\hline
\end{tabular}

ismeretek elsajátítását célzó modulok beépítése az alapképzések és mesterképzések tanmeneteibe, függetlenül attól, hogy az a Mezőgazdaság- és Környezettudományi Karon, vagy pedig a Gazdaság- és Társadalomtudományi karon valósul meg. Ezen túlmenően a SAGITER projekt elsődleges eredménye mégiscsak az lesz, ha számba vesszük azokat az agroökológai ismereteket, amely a felsőoktatási tankönyvekben nem szerepelnek, és megpróbálunk az informális, tapasztalaton alapuló tudásnak és tudásátadásnak egy olyan keretet teremteni, ami biztosítja ennek a tudásnak a fennmaradását és esetlegesen a felsőoktatási képzésekbe való beépülését.

Köszönetnyilvánitás - Az Európai Bizottság támogatást nyújtott a SAGITER agroökológiai tudástranszfer projekt megvalósításához (Egész életen át tartó tanulás program, Leonardo Da Vinci Innováció alprogram. Projekt azonosító száma: 538785-LLP1-2013-1-FR-LEONARDO-LMP Projekt weboldala: www.sagiter.eu). Köszönetünket fejezzük ki továbbá Dr. Rácz Georginának, aki a kérdőív kidolgozásában és kiértékelésében segítségünkre volt. 


\section{Irodalomjegyzék}

Altieri, M. A. (1987): Agroecology: the scientific basis of alternative agriculture. - Westview Press, Boulder, Colorado, 246 pp.

Ángyán, J. \& Menyhért, Z. (1997): Alkalmazkodó növénytermesztés, ésszerü környezetgazdálkodás. - Mezőgazdasági Szaktudás Kiadó, Budapest.

Dezsény, Z. \& Drexler, D. (2012): Organic agriculture in Hungary. Country report. - Ecology and Farming. 3 21-23. http://www.ecologyandfarming.com/old_website/EF 2012-3\%20Organic $\% 20$ agriculture $\% 20 \% 20 \mathrm{in} \% 20$ Hungary $\% 20-\% 20 \mathrm{Z} \% 20$ Dezseny $\% 20 \mathrm{D} \% 20$ Drexler.pdf

Dover, M. J. \& Talbot, L. M. (1987): To feed the Earth: Agro-Ecology for Sustainable Development. - World Resources Institute, Washington, $88 \mathrm{pp}$.

Douglass, G. K. (1984): The meanings of agricultural sustainability. - In: Douglass, G. K. (ed): Agricultural Sustainability in a Changing World Order. Westview Press, Boulder, Colorado, pp. 3-30.

FAO (Food and Agriculture Organisation) (2003): World agriculture: towards 2015/2030. An FAO perspective. FAO, (szerk.): Bruinsma, J., Earthscan Publications, London. http://www.fao.org/3/ a-y4252e.pdf

Fehér, I. (2009): European policy context for sustainable agriculture (Chapter 4) - In: Apostolides, C. (szerk.): Thematic Guide Eight, Athen, pp. 38-44.

Francis, C., Jordan, N., Porter, P., Breland, T. A., Lieblein, G., Salomonsson, L., Sriskandarajah, N., Wiedenhoeft, M., DeHann, R. Braden, I. \& Langer, V. (2011): Innovative Education in Agroecology: Experiential Learning for a Sustainable Agriculture. - Crit Rev Plant Sci. 30 (1-2): 226-237. http://dx.doi.org/10.1080/07352689.2011.554497

Francis, C., Breland, T. A. , Østergaard, E., Lieblein, G. \& Morse, S. (2013): Phenomenon-Based Learning in Agroecology: A Prerequisite for Transdisciplinarity and Responsible Action. - Agroecology and Sustainable Food Systems. 37:1, 60-75 http://dx.doi.org/10.1080/10440046.2012. 717905

Glickman, D. (1996): Secretary's Memorandum 9500-6: Sustainable Development - U.S. Baltimore, Department of Agriculture, Office of the Secretary

Günal, H., Korucu, T., Birkas, M., Özgöz, E. \& Halbac-Cotoara-Zamfir, R. (2015): Threats to Sustainability of Soil Functions in Central and Southeast Europe. - Sustainability. 7: 2161-2188. http://dx.doi.org/10.3390/su7022161

Harnos, Zs. (1993): Sustainability: A system analytic approach. - In: Győrffy, B. (ed) Strategies for sustainable agriculture. BACCE-ARI, London-Martonvásár, pp. 21-26.

IFOAM (1972): Principles of Organic Agriculture. (jelenlegi változat letölthető: http://www.ifoam. bio/sites/default/files/poa_english_web.pdf)

OECD (2008): Environmental Outlook to 2030. - OECD Publishing, Paris. http://dx.doi. org/10.1787/9789264040519-en

Østergaard, E., Lieblein, G., Breland, T.A. \& Francis, C. (2010): Students learning Agroecology: Phenomenon-based education for responsible action. -J Agr Educ Ex. 16:123-137. http://dx.doi. org/10.1080/13892240903533053

Rovira, A.D. (1995): Sustainable farming system in the cereal-livestock areas of the mediterranean region of Australia. - In: Cook H. F. \& .Lee, H. C (eds) Soil management in Sustainable Agriculture. pp.12-30.

SARE Sustainable Agriculture Research and Education (2010): What is sustainable agriculture? http://www.sare.org/publications/whatis/whatis.pdf

Ujj, A. (2006): A talajállapot-és az elövetemény- hatás javitása köztes védőnövényekkel és kímélö müveléssel. Doktori értekezés. Gödöllő. 115 pp. 


\title{
Necessity of combining traditional and scientific agroecological knowledge in higher education trainings
}

\author{
Apolka Ujj ${ }^{1}$ and István Fehér ${ }^{2}$ \\ ${ }^{1}$ Szent István University, Faculty of Agricultural and Environmental Sciences - Institute \\ of Nature Conservation and Landscape Management, Department of Organic Farming \\ and Agri-environmental Planning, H-2100, Gödöllö Páter K. u.1., Hungary \\ ${ }^{2}$ Szent István University, Faculty of Economic and Social Sciences, Institute of \\ Management Studies H-2100, Gödöllö Páter K. u.1., Hungary \\ e-mail:ujj.apolka@mkk.szie.hu
}

\begin{abstract}
The agroecology education due to its holistic approach presents a remarkable challenge for higher educators. Identification of agroecological elements and their complicated connections require an entirely new educational strategy. SAGITER international project team focuses on the promotion of agroecological knowledge transfer, by combining science-based approach with informal knowledge resulting from everyday experiences. In order to help educators and trainers, SAGITER project team creates training modules that reflect the complexity of agroecology, and teaching tools that facilitate the knowledge transfer. In Hungary, selecting the best knowledge transfer method depends on the basic knowledge of the target group, therefore a thorough real user need assessment was carried out among BSc and MSc students. One of the priority issue of the survey was the ecological farming. Results of the survey proved that there are significant differences in knowledge level related to organic farming originate from their different level and year of study, their different orientation of study, and also the gender was a determining factor. In general it can be stated that students are familiar with the impact of organic farming on the environment, but they are not familiar with its social and economic aspects. The most significant factor that influences students' knowledge is their previous experiences acquired by practice. This result highlights the importance of the practice in higher education. As a response to the survey, we developed a training 'offer' of modules which covers those knowledge gaps that were explored during our survey: economic and social aspects of agroecology besides environmental protection.
\end{abstract}

Keywords: agroecology, organic farming, educational training, knowledge transfer, health, ecology, fairness, care 